\title{
NOTE ON KAQCHIKEL ORTHOGRAPHY
}

The orthography used most often in this book is the unified alphabet promoted by the Guatemalan Academy of Maya Languages. This alphabet was approved by the national congress in 1987 and now serves for all twenty-one Maya languages found in Guatemala. The official alphabet replaces all previous systems of orthography, and its use accounts for spellings such as Kaqchikel (instead of Cakchiquel) and K'iche' (instead of Quiché).

Following the systems of Rodríquez Guaján,Yool Gómez, Calí Semeyá, and Chacach Apén (1988: I0) and Chacach Cutzal (1990: I55), there are twenty-two consonant phonemes in Kaqchikel (Table I).

The unified alphabet has nine vowels for Kaqchikel-a, a, $e, i, \ddot{i}, o, \ddot{o}, u$, and $\ddot{u}$-which are being used in standardizing the written form of the language. The Tecpán dialect, however, can be described using only six vowels: $a, \ddot{a}, e, i, o$, and $u$. The $\ddot{a}$ is lax and in general appears only in stressed, or final, syllables that end with a consonant.

In specific instances I use the older forms of spelling: in place names prescribed by the government (such as the Department of El Quiché) and

Table 1. Kaqchikel consonants

Bilabial Alveodental Alveopalatal Velar Post-velar Glottal

\begin{tabular}{|c|c|c|c|c|c|c|}
\hline Occulsive & $\mathrm{p}$ & $\mathrm{t}$ & & $\mathrm{k}$ & $\mathrm{q}$ & ' \\
\hline Glottalized occlusive & $b^{\prime}$ & $t^{\prime}$ & & $\mathrm{k}^{\prime}$ & $q^{\prime}$ & \\
\hline Affricate & & $\mathrm{tz}$ & $\mathrm{ch}$ & & & \\
\hline Glottalized affricate & & $\mathrm{tz}^{\prime}$ & $\mathrm{ch}^{\prime}$ & & & \\
\hline Fricative & & $\mathrm{s}$ & $\mathrm{x}$ & & $\mathrm{j}$ & \\
\hline \multicolumn{6}{|l|}{ Resonant } & \\
\hline Nasal & $\mathrm{m}$ & $\mathrm{n}$ & & & & \\
\hline Lateral & & 1 & & & & \\
\hline Flap & & & $\mathrm{r}$ & & & \\
\hline Semivowel & $\mathrm{w}$ & & $\mathrm{y}$ & & & \\
\hline
\end{tabular}


in proper names that regularly appeared in the national print media in the I980s and earlier (e.g., the Rabín Ajau and Tecún Umán). However, even with these names I sometimes switch to spellings in the official alphabet to reflect more recent usages (e.g., Princess Ixmucané in I980 becomes Ixmukane a decade later).As for references to the sixteenth-century K'iche' Maya myth-history, I use the unified alphabet to write Popul $W u j$ and, in doing so, mark Maya ownership of this historic text.

My most difficult orthographic decision concerned the name of the ancient Kaqchikel capital. While it appears on government maps, in national newspapers, and all the literature for the I980 period as Iximché, I have decided to use the revised spelling, Iximche', except where the word is part of a larger proper name with its own historical context of significance (e.g., Colonia Iximché, Princess Iximché, or the Declaration of Iximché). My reasons for this decision have to do with the multiple appearances of the proper name in this work-as archaeological site, park, meeting ground for protest - as well as more recent attempts by Maya within the revitalization movement to replace the name Tecpán with Iximche' as the label for the entire municipality. The changes in spelling should remind us of the shifting and political nature of Maya orthography as well as the object(ive)s for which these words stand. 
WEAVING IDENTITIES 
THIS PAGE INTENTIONALLY LEFT BLANK 